Saint Louis University School of Law

Scholarship Commons

All Faculty Scholarship

2005

\title{
The Future of the Casebook: An Argument for an Open-Source Approach
}

Matthew T. Bodie

Saint Louis University School of Law

Follow this and additional works at: https://scholarship.law.slu.edu/faculty

Part of the Legal Education Commons

\section{Recommended Citation}

Bodie, Matthew T., The Future of the Casebook: An Argument for an Open-Source Approach. Journal of Legal Education, Vol. 57, No. 1, pp. 10-35.

This Article is brought to you for free and open access by Scholarship Commons. It has been accepted for inclusion in All Faculty Scholarship by an authorized administrator of Scholarship Commons. For more information, please contact erika.cohn@slu.edu, ingah.daviscrawford@slu.edu. 


\title{
The Future of the Casebook: An Argument for an Open-Source Approach
}

\author{
Matthew Bodie
}

The casebook has achieved a venerable status. Ever since Christopher Columbus Langdell devised the first compilation to teach his students using the case method, law professors have relied on casebooks to provide the substantive basis for their courses. In many areas of study, certain casebooks have achieved not only market dominance but generations of respect, having been first authored by a luminary in the field and now carried on by subsequent leading lights. Law students view the purchase and transportation of these massive tomes as part of their rites of passage, even as casebook prices continue to climb beyond \$Ioo. The casebook is, quite simply, the written centerpiece of legal education.

Despite its privileged position, the casebook as we know it is probably on its way to extinction. The format-a thick, heavy, attractively bound textprovides not only physical difficulties but also significant logistical ones. Casebooks can only be updated every so often. They are out of date the moment they are printed. They cannot be modified by individual professors. If non-author professors wish to use different materials, they must add supplemental materials and/or ignore the book's treatment of certain subjects. In a highly individualized profession, the casebook is a promoter of conformity: it imposes costs on any effort to deviate from it.

The technology exists for a much more adaptable approach to law school course materials. Just as legal research has moved from the tactile but cumbersome realm of books and paper into the new age of computer databases, casebooks could easily move from a hardbound, irregularly updated book into a new age of computerized course materials. The electronic casebook could be individually tailored to each professor without the need for supplemental materials. Cases, statutes, and notes could be

Matthew T. Bodie is an associate professor at Hofstra University School of Law; he will become an associate professor at Saint Louis University School of Law beginning fall 2007.

I am indebted to Rebecca Hollander-Blumoff, Orin Kerr, Ethan Leib, John Mayer, Charlie Sullivan, and Michelle Wu for their comments, and to Patricia Kasting, Lissa Mascio, and Rob Rickner for their assistance in developing and researching this topic. 
quickly inserted to meet new developments. And the whole set of materialsindeed, materials for all of a student's courses-could be easily carried around inside a laptop. Already professors have begun to create and assign their own electronic casebooks for student use. ${ }^{\mathrm{I}}$

Although the development of electronic casebooks seems so logical as to be inevitable, the way they will come about is not. Now, before the technology has taken hold, there is time to consider exactly how we should use the technology as we proceed into the future. The electronic legal text could just simply be an online version of the traditional legal casebook: a collection of cases, commentary, notes, and problems, complied by one to four professors, licensed and sold to students by one of the (shrinking number of) legal publishers. However, another possibility exists. Online law school textbooks could be the product of a collaborative effort among dozens or even hundreds of law school professors, each contributing small pieces to the overall project. Such a project would permit myriad variations for individual professors without requiring professors to research, edit, and input the materials separately. There is an analogy to such a project in the realm of new technology: software made through "open source" code. The Linux operating system is perhaps the most prominent example: tens of thousands of software writers contributing without pay to the project to develop a system that is free and usable by all. But as Yochai Benkler has discussed, examples of such collaboration-in his terms, commons-based peer production-are far more frequent than imagined. ${ }^{2}$ An open-source casebook would enable professors to collaborate on a scale that is simply impossible when hard covers and copyrights are involved.

In this article I take a closer look at the law school casebook, as well as the potential that online technology holds for such texts. I then examine the open-source movement in the realm of computer software and imagine an open-source approach to the casebook. Finally, I outline the mechanics and highlight some potential problems (and solutions) that may arise in developing this project.

\section{Law School Casebooks: Past, Present, and the Digital Future}

The story of the law school casebook is familiar to most legal academics. In I870 Christopher Columbus Langdell introduced the case method to his students at Harvard Law School. Prior to that time, Harvard students had been taught the law primarily through lectures and textbooks that focused on legal definitions and rules. ${ }^{3}$ Langdell, however, focused on actual cases and

I. See, e.g., Gary Neustadter, Contracts 2003, available at <http://www.scu.edu/law/FacWebPage/Neustadter/e-books/abridged/index.html> (last visited May I8, 2007).

2. Yochai Benkler, Coase's Penguin, or, Linux and the Nature of the Firm, iı2 Yale L.J. 369 , $3^{8 \mathrm{I}-400}$ (2002). Some of these examples, like Wikipedia or Slashdot, will be discussed later in this article.

3. Charles Warren, History of the Harvard Law School and of Early Legal Conditions in America 373 (New York, igo8). 
forced students to work through how the law had been applied in that case. ${ }^{4}$ To teach this way, Langdell needed to provide his students with the cases for their study. As he set about considering how to provide these cases, he focused on the logistical concerns:

... [T] hough it might be practicable, in case of private pupils having free access to a complete library, to refer them directly to the books of reports, such a course was quite out of the question with a large class, all of whom would want the same books at the same time. Nor would such a course be without great drawbacks and inconveniences, even in the case of a single pupil. As he would always have to go where the books were, and could only have access to them there during certain prescribed hours, it would be impossible for him to economize his time or work to the best advantage; and he would be liable to be constantly haunted by the apprehension that he would be spending time, labor, and money in studying cases which would be inaccessible to him in after life. 5

Thus, the purpose of his casebook was to provide his students with direct, unlimited, and continuous access to the cases that they would be studying.

Before the casebook industry became more standardized early in the twentieth century, most professors using the case method relied on their own materials. ${ }^{6}$ Professors including Langdell and James Barr Ames self-published their own casebooks.7 This individualization led to a proliferation of titles. At least I7I casebooks were produced prior to I9o8; $6_{5}$ of these were written by Harvard professors. ${ }^{8}$ Even as published casebooks became more widely marketed in the I89os, many professors "still preferred to create their own collections of cases to be used in their classes." "It was not until the introduction of American Casebook Series, produced by the West Publishing Company beginning in I9o8, that a standardized system of casebooks began to take over. Even with this consolidation, between I9I5 and I94I nearly Ioo casebooks were published each year. ${ }^{\text {IO }}$

Most early casebooks, like Langdell's, were little more than a compilation of cases. Cases still form the primary focus of almost every legal casebook but are now generally supplemented with additional content selected or written by the authors. The cases are introduced with commentary, followed with

4. $\quad I d$.

5. Christopher C. Langdell, A Selection of Cases on the Law of Contracts: With References and Citations vi (Boston, I87I).

6. Douglas W. Lind, An Economic Analysis of Early Casebook Publishing, 96 Law Libr. J. 95, 98 (2004).

7. $\quad I d$. at $98-99$.

8. Id. at IO2.

9. Id. at io6.

ı. Id. at ıо (citing Albert Ehrenzweig, The American Casebook: "Cases and Materials," 32 Geo. L.J. 224 (I944)). 
commentary, and supplemented with brief discussions of particular issues, often culled from law review articles. The casebook is expected to be comprehensive, covering the entire subject so thoroughly that professors need use no additional materials. ${ }^{\text {II }}$

Casebooks are of vital importance: they dictate the content of and approach to the course materials. Certainly, the academy should give great respect to such endeavors, as casebook authors are in a real sense shaping the minds of future lawyers on a very broad scale. ${ }^{12}$ However, writing a casebook is often viewed in the academy as a poor tradeoff: a lot of intensive and sometimes tedious labor in exchange for generally modest remuneration and little academic prestige. ${ }^{13}$ Of course, there are exceptions: a casebook that dominates a first-year course or required upper-level course may earn its author into the six figures ${ }^{14}$ and cement the author's preeminence in the field. For the most part, however, junior academics are warned away from taking on casebooks, as the work is not credited for tenure in the way that law review scholarship is. ${ }^{15}$

Perhaps casebooks are not accorded the prestige they deserve because they do not fit easily into a category of scholarly pursuit. Casebooks do not contain the original legal research or theory of law review articles, nor do they contain the comprehensive synthesis expected of treatises and hornbooks. In fact, casebooks must be comprehensive to some extent but must also explicitly leave some analysis for the students to undertake themselves. ${ }^{16}$ For this reason, casebooks may have a limited shelf life. They generally cannot substitute for a treatise after students become attorneys and need to apply the law in practice. ${ }^{17}$ At most, they may jog the memory and set forth one or two of the seminal cases on the issue. Even students are relying less and less on casebooks to learn the law. A bewildering assortment of treatises, outlines, study aids, flow charts, practice questions, and interactive software programs

II. Despite this comprehensiveness, many books assume that professors will also require supplements containing statutes, model codes, and restatement provisions.

I2. See Richard E. Speidel, Edward J. Murphy: The Man and the Casebook, 7I Notre Dame L. Rev. 571, 572 (1996) (discussing his "best estimate" that over 80,0oo law students had used the contracts casebook authored by himself and Edward Murphy).

I3. See Arnold H. Loewy, Building a Better Casebook, 42 Brandeis L.J. 267, 267 (2003-2004) ("Editing a casebook is neither easy nor exciting. It can be tedious, time consuming and rarely as fulfilling as developing one's 'brilliant' idea into a law review article."); Myron Moskovitz, On Writing a Casebook, 23 Seattle U. L. Rev. IOIg, IO2I (2000) (noting that a potential casebook author is unlikely to make more than "four figures").

I4. The monetary figure was provided confidentially by a third party.

15. Janet Ainsworth, Law in (Case)Books, Law (School) in Action: The Case for Casebook Reviews, 20 Seattle U. L. Rev. 271, 272 (1997) ("[Y]oung untenured faculty are counseled by their senior colleagues not to waste time working on casebooks.").

I6. Many casebooks have comprehensive references to issues that arise in a particular area but phrase those references as questions, and thus require students to look up the cases to find the answer.

17. Robert Laurence, Casebooks are Toast, 26 Seattle Univ. L. Rev. I, 4 (2002). 
are available to help students through their coursework. Perhaps I am not the only professor to have a student cite a study aid on an exam. ${ }^{18}$ Casebooks are just a starting point for many students, a piece within a collage of materials necessary to achieve an understanding of the law.

Casebooks are also a somewhat clumsy way of accomplishing the pedagogical needs they seek to fulfill. By its nature, the casebook imposes a standardized set of materials on the professors who use it. Because their notion of the proper course materials is likely not to match perfectly with that of the authors, most professors feel the need to "edit" the casebook by leaving out some materials and adding others. The syllabus must carefully indicate which cases, notes, or other materials are to be read, and which are to be skipped. Students must also attend to the distribution of additional materials which the professor has compiled. To round out the package, many courses require a statutory supplement, often overstuffed with statutes, regulations, interpretations, and model codes that the class will never discuss. While bemoaning such logistical hurdles may seem trivial, these difficulties detract not only from the elegance of the presentation but perhaps even from its pedagogical effectiveness. ${ }^{19}$ Students may see materials not in the actual textbook as extraneous or not as significant. Photocopied cases are easier to lose; if not properly catalogued, the student may not even realize they are missing a case. And if a professor relies too heavily on photocopied materials along with a textbook and statutory supplement, students may wonder why they have spent substantial sums for the books in the first place.

Thus, professors face a dilemma when it comes to crafting their own course materials. Most professors use one of the established textbooks in the field and, depending on the subject, there may be a substantial array of texts from which to choose. ${ }^{20}$ Nevertheless, unless the professor has written the text her- or himself, no casebook completely maps what the professor wants to cover or the pedagogical approach the professor favors. ${ }^{21}$ If each professor had the time and initiative to create his or her own casebook, these books would be like snowflakes: no two would be exactly alike. However, moving away from the text by adding supplemental materials takes a fair amount of time. The professor must first discover the materials. Professors may find these materials through direct course-material research, or they may be by-products of scholarly research or perhaps old

I8. On a take home exam, no less!

I9. See Gary Neustadter, Rethinking Electronic Casebooks, Jurist (1998), available at <http://jurist.law.pitt.edu/lessons/lesjung8.htm> (last visited July Io, 2007) (discussing the inelegance of "editing" someone else's casebook).

20. E. Allan Farnsworth, Casebooks and Scholarship: Confessions of an American Opinion Clipper, 42 Sw. L.J. 903, 905-906 (ig88) (discussing the "scores" of contracts textbooks available authored by "some fifty contracts professors").

2I. See Loewy, Building a Better Casebook, supra note I3, at 268 (saying that "the [casebook's] order is so idiosyncratic that it would be surprising if there weren't substantial disagreement about the order of a casebook"). 
practice experience. Once the materials are found, they have to be edited, compiled, and sent for distribution. Nothing terribly difficult, but it takes time, coordination, and assistance.

As a result of the time, effort, and inconvenience to both students and professors in creating and using supplemental materials, I suspect that most professors rely more on the casebook for their source materials than is their pedagogical preference. Perhaps this is not really a problem; perhaps the standardization imposed by textbooks is good for the profession. Certainly, the notion that law professors across the country are all teaching the same subject using one of a handful of different texts, each of which may have substantial overlap with the other texts in the field, lends itself to a national sense of what the "law" is, at least from a students' perspective. But such standardization also stifles creativity and encourages unnecessary homogeneity. It sustains the myth that there is a "brooding omnipresence" of national law when, in most first-year courses, we have instead a system of state-based common law. ${ }^{22}$

Another problem for many professors is that they may come to rely on a certain casebook and then feel abandoned if the book changes directions. Periodically authors need to adapt their books to new developments and cases; they may even want to try entirely new pedagogical approaches. Their loyal users must adapt themselves to whatever changes the authors have imposed on them, even if they disagree with the change. The authors may decide to completely rewrite a section that was (in its prior form) beloved by some of its users. No casebook author wants to come up with the equivalent of "New Coke." But neither can a book ignore new issues or approaches without becoming stale and out of date. Inevitably, no choice will satisfy all parties. If significant changes are made, old users may feel trapped in a bad relationship: their old book has changed for the worse, but there is nowhere else for them to go. ${ }^{23}$

In sum, the existence of hard-bound casebooks imposes costs on efforts to deviate from the casebook materials. Because of these costs, most professors

22. See, e.g., S. Pac. Co. v. Jensen, 244 U.S. 205, 222 (I917) (Holmes, J., dissenting) ("The common law is not a brooding omnipresence in the sky but the articulate voice of some sovereign or quasi-sovereign that can be identified....”). Overreliance on opinions by certain judges and/or schools of thought may contribute to a student's notion of a nationalized common law. See Mitu Gulati and Veronica Sanchez, Giants in a World of Pygmies? Testing the Superstar Hypothesis with Judicial Opinions in Casebooks, 87 Iowa L. Rev. II4I, II 6-47 (2002) (discussing the dominance of opinions by members of the "Chicago School" of Law and Economics in law school casebooks).

23. An example of such a change is the decision by Melvin Eisenberg to rearrange Lon Fuller's Contracts casebook so that it began not with remedies, as Fuller had made famous, but with formation. See Scott D. Gerber, Corbin and Fuller's Cases on Contracts (1942?): The Casebook That Never Was, 72 Fordham L. Rev. 595, 626 (2003). This decision brought harsh criticism from other professors, who saw Fuller's original ordering as a "powerful symbol" of the acceptance of legal realism by the academy. Alfred S. Konefsky, Elizabeth B.Mensch, and John Henry Schlegel, In Memoriam: The Intellectual Legacy of Lon Fuller, zo Buff. L. Rev. $263,263-64$ (I98I). 
change those materials less than they otherwise would if those costs could disappear. Fortunately, new technology enables professors to reduce those costs dramatically. The shift of legal materials from books to online databases has opened up the potential for a completely computerized version of the casebook. Instantly, a number of the problems with casebooks could be solved. Electronic materials can be quickly and easily edited. A case can be included as soon as it is published, a statute included as soon as it is passed. Moreover, individual professors could easily add to and subtract from the materials. Students could access these materials from wherever they have Internet access or a copy of the relevant data file; no more worrying about whether the book is at home or whether the photocopied materials have been lost. Although the impressive gold-relief binding would be lost, so would the back-breaking weight.

There are many ways to create an online casebook. The simplest departure from the current state of affairs would be to place a preexisting law textbook onto a database accessible to both teacher and student. This move could be accomplished in several ways. One method would be to put the whole textbook into one text file that could be accessed by the professor and students. Another way would be to break the textbook down into component chapters, sections, or subsections, and put each piece into its own separate file. The breakdown could go even further, and each piece of text-say, commentary, edited case, or law review excerpt-could have its own file. The professor would then have to reassemble the pieces, either by putting the individual files into one combined file or by creating an outline that provided some structure to the materials. ${ }^{24}$ Although this may seem complicated, proper organization of the filing folders plus some working knowledge of the subject would enable a user to pick and choose between materials simply by looking at the name of the computer file.

Moving a preexisting casebook from the printed page to a computer file or files would make changes to the text much easier. Professors could directly delete those materials that they did not want the students to cover. ${ }^{25}$ They could insert additional materials right into the casebook file or into the overall outline for the course. The end product would be a seamless compilation of the course materials. Since it would be easier to add materials-no additional distributions to photocopy and distribute-professors might be more likely to add and subtract than they currently are. Digital casebooks would empower professors to take control of their course materials. ${ }^{26}$

24. For another description of this process, see Neustadter, Rethinking Electronic Casebooks, supra note Ig.

25. I am assuming that the casebook could be modified to at least delete those materials that the professor did not wish to include. It would be possible to put a casebook into a single, unalterable file, such as an Adobe Acrobat (pdf) file, but that would defeat much of the purpose of putting the textbook on line in the first place.

26. The format of the digital distribution would affect the professor's choices down the road. If the casebook were distributed at the beginning of the class as one compiled file, then the professor would be unable to change materials during the length of the course without 
The current online technology makes it easier for professors to develop their own casebook. Some professors have long eschewed casebooks in favor of a compilation of photocopied materials, usually put together over time by the professor in a format similar to a casebook. Composing these materials is essentially the equivalent of creating one's own casebook. Using word processing technology, however, the professor could more seamlessly compile and edit these materials, rather than physically cutting and pasting them. An even easier path exists for those professors willing to use a preexisting online database. The professor could simply download the materials used for the course to a webpage, or post hyperlinks on the webpage to the materials inside the database. Robert Laurence describes the experience of one professor in creating a "coursebook" in this manner. ${ }^{27}$ Laurence used the Lexis/Nexis webpage system to create an online casebook. ${ }^{28}$ He posts "chapters" with links to cases and statutes, as well as his own annotations on those materials. ${ }^{29} \mathrm{He}$ generally does not edit the cases or statutes. ${ }^{\circ}$ Laurence has created his own virtual casebook by relying on his own commentary and original materials supplied by Lexis. $3^{\mathrm{I}}$

Laurence believes that his online casebook provides a superior alternative to the traditional casebook. He can tailor the materials to cover certain topics in much more depth, particularly issues that are of local but not national interest. $3^{2} \mathrm{He}$ can adjust the materials easily if a certain topic becomes more of a class focus, or if other materials must be eliminated for time reasons. 33 The students save money on textbooks and are not stuck having to sort through a collection of hard-copy materials. ${ }^{34}$ Overall, Laurence is so happy with his online casebook experience that he thinks regular casebooks are "toast."

However, Laurence discusses two cons in his online experience. First, he admits that compiling an online textbook takes a significant amount of time. 35 Although claiming that it certainly takes less time than compiling

resorting to the usual methods. If the materials were posted to a database, however, the professor could add or subtract materials throughout the course. Last minute changes could be made without worrying about the distribution requirements or the confusion it might engender in students.

27. Laurence, Casebooks are Toast, supra note 17, at 2-4.

28. Id. at $2-3$

29. Id. at $3-4$.

3o. Id. at 6

31. See also Neustadter, Rethinking Electronic Casebooks, supra note i9 (describing how an electronic casebook could use its own digital libraries rather than materials from an online database).

32. Laurence, Casebooks are Toast, supra note $\mathrm{I} 7$, at 5-6.

33. Id. at 2 .

34. Id. at 5 .

35. Id. at 8 . 
a nationally published casebook, Laurence does seem concerned enough about the time spent that he thinks professors need a buy-in from their dean. ${ }^{3}$ He seems somewhat resigned that his work will garner him little institutional or academic prestige, but he feels the benefit to his students is sufficient reward. ${ }^{37}$ As for the second concern, Laurence acknowledges that he relies on the Lexis webpage system, and that all of his students must have Lexis identification numbers to participate. $3^{8}$ Since his students are entitled to free Lexis and Westlaw access, he is not too concerned about this reliance. He does have a twinge of concern about his method of posting cases: rather than linking to a case or statute within the Lexis database, he downloads the file to his computer and then reposts it to the course database. ${ }^{39}$ Laurence is unsure about the copyright issues in such a system, but assumes that since he is working within the Lexis system with students who all have free Lexis access, there are no copyright violations. ${ }^{40}$

Although Laurence has created his online textbook in spite of these difficulties, I think they pose serious challenges to more widescale adoption of his method. First, the primary attraction of the casebook is the savings in time and effort in developing course materials. Even though Laurence's online course materials do not take as long to develop as a casebook, they do take a substantial period of time. The more individualized and specialized the materials are, the more work it will take to develop them. Second, the professor and students are very much dependent on the database provider for the continuing existence of the coursebook. Without Lexis or Westlaw, Laurence would be unable to create his online textbook unless he individually copied every case, statute, or law review article to a separate database under his control. And if he copied the materials directly from Lexis, he would almost certainly be guilty of violating the Lexis copyright on those materials..$^{4}$ Thus, the whole system is dependent on the current decision by Westlaw and Lexis-and with affiliated casebook publishing houses-to allow students and professors to use the webpages and materials for free. If most professors suddenly decided to adopt Laurence's method, I wonder whether Lexis and West would watch their casebook publishing businesses disappear without attempting to recoup the lost money through their webpage and database services.

Laurence's online casebook is not a free and easy solution. But there is a way to minimize the difficulties described above while retaining many of the

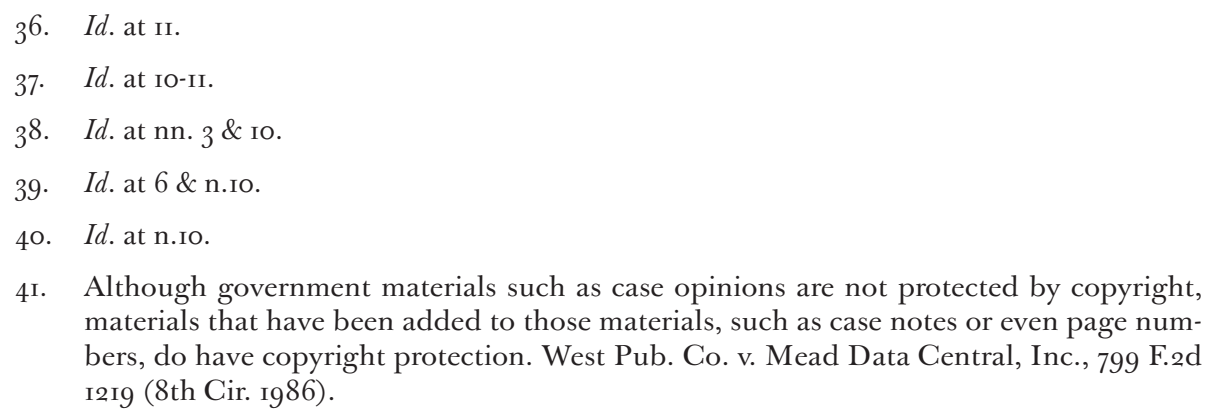


benefits Laurence describes. The work of compiling a new set of materials could be broken down and parceled out across the whole academic community. And a system could be put in place that was not dependent on Westlaw, Lexis, or any other database provider who owned ultimate property rights over the materials. Such a system would be modeled on the communal system that has developed what is known as open-source software.

\section{An Open-Source Approach to Law School Casebooks}

Open source refers to a revolutionary approach to the production of computer software. The term itself refers to the source code used to write software. Software owned by private companies-referred to as proprietary software-keeps this source code secret. Innovations and further developments to the software can only be made by the company and its team of programmers. Open-source software, on the other hand, reveals its code and thus makes its internal workings known. Users can thus make changes and apply new innovations directly using the program's source code..$^{42}$

Although open source refers to an approach to programming, in a more general sense it refers to the many software projects that have been undertaken using the open-source approach. When computers were initially developed, all computer software was freely accessible and adaptable because it was tied directly to a particular hardware producer and not economically alienable. ${ }^{43}$ However, as computers grew in importance and interactivity, software companies began protecting their software with copyright restrictions. ${ }^{44}$ In response to the growth of proprietary software, hacker and MIT researcher Richard Stallman founded the Free Software Foundation (FSF). 45 Stallman's goal, as he expresses it, is to "spread freedom and cooperation. I want to encourage free software to spread, replacing proprietary software that forbids cooperation, and thus make our society better." ${ }^{6} 6$ The most famous open-source project is the GNU/Linux operating system, which was begun by Linus Torvalds in the early r99os. ${ }^{47} \mathrm{GNU} /$ Linux was designed as an opensource competitor to operating systems such as IBM's DOS and Microsoft's Windows. Although Linux is the best known open-source project, there are literally thousands of open-source projects, and many of these have achieved a level of market dominance. One example is a type of software known as

42. David S. Evans and Anne Layne-Farrar, Software Patents and Open Source: The Battle over Intellectual Property Rights, 9 Va. J.L. \& Tech. Io, $\mathbf{9}_{3}$ (2004).

43. See Lawrence Lessig, Free Culture: How Big Media Uses Technology and the Law to Lock Down Culture and Control Creativity 279 (New York, 2004).

44. Id.; Evans and Layne-Farrar, Software Patents, supra note 42 , at $\mathbb{9}_{4}-\mathbf{I}_{5}$.

45. Evans and Layne-Farrar, supra note 42 , at $\mathbf{9}_{5}$.

46. Id. at $\mathbf{I}_{5}$ n. Io (quoting Richard Stallman, Copyleft: Pragmatic Idealism, Free Software Foundation, available at <http://www.gnu.org/philosophy/pragmatic.html> (last visited June 29, 2007)).

47. Evans and Layne-Farrar, Software Patents, supra note 42, at $\mathbf{9 6 .}$ 
sendmail which routes over 85 percent of e-mails..$^{8}$ The GNU/Linux operating system is itself steadily gaining ground and runs on about 30 percent of the servers connected to the World Wide Web.49

Two developments relating to open source have drawn an increasing amount of scholarly attention. First, open-source software takes a unique approach to intellectual property protections. Open-source programs are generally designed to be shared, changed, adapted, and passed on from user to user to user. The author of an open-source project is not seeking to protect that software from duplication, competition, or other types of encroachment; indeed, that encroachment is part of the process. Because of the uniquely adaptable nature of software, however, a single "bad actor" could take an existing public domain program, make a slight adaptation to it, and then copyright the new program, removing it from the system. Open-source software has developed a specific type of intellectual property license to prevent this..$^{\circ}$ This license specifies that others are allowed to use and modify the program, but that the original code does not become copyright protected merely by its inclusion in the new product..$^{5}$ Perhaps the most well-known license is the GNU GPL: this license requires that all derivative works be licensed as a whole without any charge to third parties..$^{2}$

The second development is the phenomenon of open-source production itself. One of the most fascinating things about the open source movement is that it exists at all. Economic models do not predict that hundreds of programmers would devote their free time to uncompensated labor that could be (in many cases substantially) compensated in other circumstances. Yet that is what is happening. Sociologists, economists, and law professors are continuing to explore why thousands of programmers donate time to such an enterprise. 53 But it is undeniable that open-source software now factors in the provision of dozens of types of software applications.

48. Yochai Benkler, Freedom in the Commons: Towards a Political Economy of Information, 52 Duke L.J. I245, I256 (2003).

49. Id. at I257. For a more in-depth discussion on lesser-known open-source projects, see Eric S. Raymond, The Cathedral \& the Bazaar: Musings on Linux and Open Source by an Accidental Revolutionary (Cambridge, Mass., 200I).

5o. David McGowan, Legal Implications of Open-Source Software, 20or U. Ill. L. Rev. 24I, $253-54$.

5. $\quad I d$.

52. Id. at 255 .

53. See, e.g., Yochai Benkler, Intellectual Property and the Organization of Information Production, 22 Int'l Rev. L. \& Econ. 8I (2002); Eric A. von Hippel and Karim Lakhani, How Open Source Software Works: "Free" User-to-User Assistance?, MIT Sloan Working Paper 4II7-00 (May 2000), available at <http://ssrn.com/abstract=290305> (last visited July IO, 2007). 
However, open source is not the only example of what Yochai Benkler has identified as "commons-based peer production." 54 Benkler describes this model of production as "large-scale cooperative efforts in which the thing shared among the participants is their creative effort." 55 Scientific research is one such example: thousands of individuals working on projects to contribute to the overall pool of scientific knowledge. $5^{6}$ However, the Internet has enabled a whole new set of discrete projects using peer production. The examples are numerous. The NASA Clickworkers project enlisted volunteers to help map the landscape of Mars. More than $8_{5}$, ooo volunteers, spending as little as five minutes, helped provide maps that are "virtually indistinguishable from the inputs of a geologist with years of experience." ${ }_{57}$ The Wikipedia project involves roughly 75,00o participants working on a web-based encyclopedia. Entries to the project have grown from 30,000 in 2002 to over I. 8 million in $2007.5^{8}$ There are now versions of Wikipedia in seven different languages, each with over 250,000 articles.59 The Wikipedia Foundation is now working on a Wiktionary, a biological species repository known as Wikispecies, and numerous other Wiki-oriented projects. ${ }^{60}$

So what would an open-source approach to law school casebooks look like? The purpose of establishing an open-source approach would not be simply to take advantage of online technology; after all, traditional legal publishers can adapt their textbooks to the online format. The reasons for pursuing an open-source system would be to encourage greater flexibility and individuality in course approaches, while at the same time allowing all law professors to collaborate on course materials at levels heretofore impossible.

An open-source casebook would need three primary components to get off the ground: software to establish the database; space on a server to hold and develop the database; and a manager or managers to set up and run the overall system. Essentially, an open source casebook would be a database with an assortment of potential components that individual

54. Benkler, Coase's Penguin, supra note 2, at 375 .

55. Yochai Benkler, Sharing Nicely: On Shareable Goods and the Emergence of Sharing as a Modality of Economic Production, II4 Yale L.J. 273, 334 (2004).

56. Benkler, Coase's Penguin, supra note 2, at $38 \mathrm{I}-82$.

57. Id. at $3^{84}$ (quoting NASA, Clickworkers Results: Crater Marking Activity (July 3, 200I), available at <http://clickworkers.arc.nasa.gov/documents/crater-marking.pdf> (last visited July IO, 2007)).

58. See $i d$. at $3^{86}$ (discussing 2002 figure); Wikipedia, available at <http://en.wikipedia.org/ wiki/Main_Page> (last visited June 29, 2007) (discussing current figure).

59. See Wikipedia, available at <http://en.wikipedia.org/wiki/Main_Page> (last visited June 29, 2007). In addition there are Wikipedias in eighteen additional languages that have over 50,000 articles, and there are thirty-four additional versions with over I, Ooo articles. Id.

6o. Ingrid Larson, Wikipedia Needs Help to Keep Growing, ZDNet UK, Mar. I, 2005, available at <http://news.zdnet.co.uk/software/developer/o,39020387,39189592,oo.htm> (last visited July I0, 2007). 
professors would then assemble into individualized casebooks. The managers would need to organize the materials in ways that allow outside professors to navigate these components with little difficulty. Managers might also take a more active role by soliciting certain types of contributions or creating casebook "prototypes." And perhaps discussion groups, either managed on the web or through an e-mail listserv, would provide explanations and updates on the latest the database had to offer.

As an illustration, suppose two or three professors want to create an opensource casebook for a first-year Contracts course. The professors would first have to set up a database using appropriate software. They would need to secure space on a server to use for the database. The database itself would have to be accessible through the Internet, although they could establish a password system limiting access only to those who joined their group. Once the database was established, the component parts of the casebook would then be downloaded into it. Other professors could then access the site, copy the component parts to their own computer, and assemble the parts into a textbook. Ideally, the Contracts database would have a wide variety of components from which to choose. To get the greatest benefit out of open-source production, the initial professors would also need to manage contributions so that other professors could easily find what they were looking for on the site.

What would be the component parts to the casebook? They would include primary legal materials, such as cases, statutes, regulations, and even opinion letters or legislative history, as well as secondary legal materials, such as model codes, restatements, law review articles, scholarly books, and even nonlegal periodicals. There is also original material such as commentary, sample problems, and case notes. The open-source database managers would have to manage all of these types of materials to allow professors to create their own textbooks. Each would present its own intellectual property issues, which are discussed further below. But first, I hope it is clear that if all of these materials were available, individual professors could assemble their own textbooks simply using the database components. For example, a professor compiling a Contracts textbook would need a section on the Statute of Frauds. The professor might create the section by downloading the following components: an explanatory section outlining the basics of the Statute; an edited version of the Statute itself, perhaps from the school's own state; cases relating to different aspects of the Statute; commentary and case notes on one or more of these aspects; and finally problems relating to the material studied. All of these materials could be included in the open-source database, ideally offering a wealth of different choices.

In addition, different users could upload their compilations to the database as well. A professor new to the subject and not sure how best to compile the many offerings might look to one of the pre-compiled sets of materials downloaded to the commons. For example, an experienced professor might use the commons to select each component and then put those materials together into the equivalent of an online casebook. The professor might set up her own database with the 
available materials, or she might put all of the materials into a single text file. The professor could then either post a link to her database on the commons, or she could upload her text file to the casebook database. Others would then be able to use that compilation as the basis for their own course materials.

To make a culinary comparison, a commons casebook database would be like a kitchen with all of the ingredients necessary to make a casebook "dish." Each cook could use the ingredients as she saw fit, and each final dish would probably be different. As more and more cooks used the kitchen, more and more ingredients would be added, making the possibilities for each dish even greater. But for those cooks who were new or did not want to invest the same amount of time in preparing their dish, others cooks could leave recipes or even frozen dishes in the freezer to be used by them. Thus, the commons casebook kitchen could accommodate all levels of chefs, from the novice to the Michelin three-star.

I cannot say for sure that an online commons casebook would actually work. The obstacles to such an endeavor could be grouped into three categories: lack of motivation, or the problem of too little; lack of manageability, or the problem of too much; and copyright difficulties. Each of these will be taken in turn.

\section{Lack of Motivation, or the Problem of Too Little}

Before an open-source casebook can take off, the online architecture has to be constructed. As noted above, these are not insignificant requirements: an operational database, sufficient hardware to support the database, and a manager or managers to keep the system going. However, once these are in place, the casebook would need users to provide the content. Who is to say that once it is built, they will come?

A key assumption to the success of such a venture is that many professorsenough to generate a wealth of content-are interested in having more control over their course materials. Despite the cost savings associated with casebooks, a significant number of professors nevertheless develop their own materials; they would be obvious recruits to an online casebook project. An online commons of materials would allow professors the flexibility they seek without the need of editing, commenting, and compiling the materials individually. For some individual compilers, the cost of changing over to a new system might be fairly high. If a professor is using her own materials, but these materials have been edited by hand and are now easily photocopied with only occasional changes, the changeover might be difficult. These start-up costs will be discussed further below. But if these materials were transferred to electronic form, either by the professor or by administrative support, they could easily be uploaded (piece by piece) to the casebook database. Once that was done, the professor would then have access to cases, commentary, and other material used by other professors. Instead of relying on personal research and awareness for new material, the professor could look to the database for the combined wisdom of her peers. Instead of editing each case as it came out, the professor could see if someone else had already tackled the project. Instead of relying solely on her 
own initiative and ingenuity in developing problems or commentary, she could use materials developed by other professors.

Of course, there would be significant startup costs for some professors. In fact, even professors who have an electronic version of their materials might have to start over, if they are using copyrighted versions of cases, statutes, or commentary. And if it appears that only a handful of professors would be interested in such an endeavor, then the tradeoffs might not be worth it. But if the site were to be up and running with a critical mass of participants, the commons casebook would save professors a ton of time in assembling their own materials. Such individualists would get all of the flexibility they crave while doing less work and getting free insights from their peers.

So how about the majority of professors who use casebooks developed by another professor or professors? Would they contribute to an online commons casebook? At present, they are satisfied enough with the offerings available to rely on the work of others. Why would they want to take time away from research or leisure to compile their own?

First, it should be noted that the commons casebook would flourish even with some percentage of participating professors who contributed nothing to the project. While I'm not sure of the critical mass required to make the online project a viable alternative, certainly the system could allow a healthy number of free riders who contributed nothing to the project. A free rider need not even compile her own set of materials; presumably, the database would have not only the individual case and commentary modules but also other professors' compilations. Thus, the free rider could continue to use materials compiled by others without needing an old-fashioned casebook.

Nevertheless, an online commons project would probably need at least some input from former casebook users to be successful, with a strong emphasis on "some." As Benkler recognizes, "[p]eer production is limited not by the total cost or complexity of a project, but by its modularity, granularity, and the cost of integration." ${ }^{\text {r }}$ The online casebook is ideally situated in these respects. Modularity refers to the extent to which a project can be "broken down into smaller components, or modules, that can be independently and asynchronously produced before they are assembled into a whole." ${ }_{2}$ A professor need only contribute a single edited case, a single hypothetical problem, or a single piece of academic commentary to the commons at any particular time. Initially, the commons manager(s) might seek to divvy up the work among participants to insure proper coverage. Ultimately, however, participants need only post whenever they find something interesting or relevant. These modules thus also have fine "granularity": there is not a huge amount of time or effort required to make any particular submission. It should be noted that editing a case is a lot easier than writing a chapter introduction, and there may be more cases and less commentary as a result. But again, it is a lot easier to write an

6r. Benkler, Coase's Penguin, supra note 2, at 435 .

62. $I d$. 
introduction about the Statute of Frauds than it is to write the commentary for an entire casebook, which is currently the level of granularity required. Finally, with regard to the cost of integration, professors need not reach agreement on how to compile the materials. Each professor can assemble the materials as she so desires.

It is a strength of the online commons casebook that it would allow for a variety of levels of input. As Benkler notes, "[h]eterogeneity [in the size of contributed modules] allows contributors with diverse levels of motivation to collaborate by contributing modules of different sizes." ${ }^{163}$ One can easily imagine that some professors would contribute all of their own materials, sufficient to stand alone as a casebook; others would contribute cases or commentary in their areas of research; and others would add an occasional case or regulation when they come across something interesting. And one can easily imagine that professors will have varying levels of interest and enthusiasm for the collaboration. Again, this is a strength: "A project that allows highly motivated contributors to carry a heavier load will be able to harness a diversely motivated human capital force more effectively than a project that can receive only standard-sized contributions." ${ }^{4}$

In fact, it may be that those who are most interested in contributing to the online collaboration will be those with their own casebooks. ${ }^{65}$ Many casebook authors are motivated by a desire to develop the right materials for their own courses. ${ }^{66}$ Developing these materials using an online commons database would be easier and faster and would free up the authors' time for other projects. Certainly, royalties and the prestige of having one's own book are important incentives. But an important online contributor would still get recognition and prestige from her peers for her contributions. As will be discussed further below, commentary written by a leader in the field will presumably generate more interest and discussion than commentary from a novice. A wellwritten piece of commentary might also get a newer professor some recognition and contacts in the field. No longer would the casebook author reach only those professors and students who use that casebook. Instead, a much broader cross-section of scholars and students may read one professor's discussion of,

63. Id. at $43^{6 .}$

64. Id.

65. It is important to note that casebook authors may be legally prevented from working on a commons casebook. According to one author, his casebook contract prohibits him from working on any form of competing project. The provision reads: "For the life of this agreement, the Authors agree not to write, edit, or otherwise contribute to any work that might in the reasonable opinion of the Publisher, compete directly with or injure the distribution of copies of the Work...." A commons casebook, even if completely nonprofit, might still be deemed to "compete directly with or injure" sales of the author's published casebook.

66. See Moskovitz, On Writing a Casebook, supra note I3, at IO2O-2I (pointing out that he wrote his textbook because none of the available casebooks were organized around his pedagogical approach). 
say, the Statute of Frauds, if that discussion were particularly well-written and insightful. ${ }^{67}$

Ultimately, I cannot be sure that professors would contribute to online commons casebooks. There would seem to be enough professorial interest in both tailoring one's own materials and collaborating with others that such a project would be successful. ${ }^{68}$ In fact, professors have successfully created a collaborative casebook: since 1946 members of the Labor Law Group have jointly produced casebooks for labor and employment law. ${ }^{69} \mathrm{~A}$ paper by W. Willard Wirtz served as a springboard for the Group, which jointly compiled the casebooks and published them through a series of legal publishers. The money from the sale of the textbooks was placed in a common law trust, which was used to facilitate the Group's projects..$^{\circ}$ One participant looked back on the experience as an "exhilarating" chance to work with colleagues in developing a joint product in their field of academic interest..$^{71} \mathrm{It}$ is interesting to note that in I970, Wirtz proposed a new casebook made of modules: "each teacher would have the freedom to make his or her own judgment of what should be included, the teacher would notify the publisher, and the magic of modern production techniques would turn out a tailor-made book for that small community." $7^{2}$ Ultimately, the project was cramped by the inherent practical publishing difficulties at the time and never achieved the anticipated success. ${ }^{73}$

The beauty of the online commons casebook is that it combines the best of both worlds: it facilitates collaboration with colleagues and allows for individual flexibility. I think the benefits would lead law professors to participate in such a system. What if, however, the project were too successful? How could the participation of hundreds of professors be properly managed?

\section{Lack of Manageability, or the Problem of Too Much}

If the online commons casebook became popular enough, it might soon have a different problem: a lack of manageability. If too many people were uploading too many files to the database, the database could become

67. See $i d$. (discussing the benefits of name recognition and contact with other professors that come from writing a casebook).

68. See John E. Dunsford, In Praise of Casebooks (A Personal Reminiscence), 44 St. Louis U. L.J. 82I, 825 (2000) ("Lives there a law school teacher with soul so dead who never to himself has said: 'Why not assemble my own teaching materials and cases?").

69. Id. A recent casebook from the Group is Robert J. Rabin, Eileen Silverstein, and George Schatzki, Labor and Employment Law: Problems, Cases and Materials in the Law of Work (3d ed., St. Paul, Minn., 2002). Copyrights in the work are held by the West Publishing Company and the Labor Law Group.

70. Dunsford, In Praise of Casebooks, supra note 68, at 825 .

7I. Id. at $826-27$.

72. Id. at 827 .

73. Id. at $827^{-2} 8$. 
impossible to wade through. There are many ways of editing a case; who wants to read forty different edits of Pennoyer v. Neff? Commentary and case notes could be even more problematic; there could be a lot of duplication between sources, and users would conceivably need to look over every entry to get a true sense of what was available. How could such a wealth of materials be managed?

Creating the right architecture for the database would be an important initial step. The database would need a structure that allowed for diverse inputs while at the same time making them easy to find. As noted earlier, this would probably start with creating a system of online file folders organized like a table of contents. In a Contracts database, Statute of Fraud cases would be in the Statute of Frauds folder, but the managers would probably want to break it down further: there might be folders for the oneyear rule or UCC $\$$ 2-2OI. Managers might need to patrol the database periodically to make sure that folders are added or deleted as necessary. Next, managers might want to create a simple membership system to prevent hackers or spammers from tampering with the system. Most managers would probably opt to allow any interested professor access to and participation in the database. But the simple step of requiring professors to register would filter out some potential manageability problems.

Even with this organization, however, there might still be problems of duplication and undue proliferation. What would make the database even more useful would be additional information about the entries that could quickly be ascertained. The managers could set up the database so that each file listed the name of the user who uploaded that file. This identification would give more of an incentive to do a quality job. In addition, if a contributor developed a reputation as a careful and judicious case editor, other users might look for her upoads in compiling their materials. As noted earlier, commentary posts by leading lights in the field would undoubtedly get special attention, but lesser known users could also develop reputations for their work. In a community where many of the participants know each other fairly well, seeing a name along with the file would provide important information to other users.

The commons manager could also enable users to post comments or even ratings about each upload. Users would be allowed to post comments about each file-perhaps of limited length-to provide context and evaluation. Users could be asked to rate the usefulness of each upload, or indicate if she is actually using the particular file in her own materials. Like the download counters used on the Social Science Research Network website, a "user counter" would provide a quick gauge of the popularity of a particular file. ${ }^{74}$ That evidence

74. I think a user counter would be more helpful than a download counter, because a download counter would only indicate how many people looked at a particular file, not how many found it helpful. However, a download counter would work automatically, while a user counter would require actual input from the user, often requiring a subsequent visit to the site. 
would be useful and easily ascertainable. At Slashdot, the technology-related website of commentary from hundreds of users, there is a complex peer review system to indicate which submissions are of highest quality and of most relevance to a particular user. ${ }^{75}$ Such a system could be developed for commons contributions as well.

Casebook authors and publishing house editors may think that I have given short shrift to the work required in compiling and editing the entirety of the casebook. Although professors may be able to stitch together a casebook from a grab-bag of legal odds and ends, publishers might argue that the end product will lack the seamless beauty of a traditional casebook. Moreover, no editor will be there to review the final product, suggest changes in length and ordering, and refine the end result. These criticisms are valid concerns. Casebooks compiled through the online commons database will likely not resemble casebooks written by one author with a strong theoretical bent, such as Randy Barnett's Contracts casebook..$^{6}$ And without a monetary incentive, it could be argued, lone authors will not have the time or ability necessary to devote to these projects.

Three responses may mitigate these concerns. First, for those who prefer such an approach, there is nothing to prevent the continued publication of such works. Ultimately, there is room for both copyrighted and commons casebooks, and for those authors who wish to continue with the traditional route, there is nothing to prevent law professors from continuing to use their product. Second, the online commons casebook would take advantage of "editors" in the form of other law professors. Professors would comment on others' work, post their own edited versions of posted material, and set forth their ultimate compilations of the materials. Although professors could work on their compilations in private, ideally there will be a wealth of information available to them to help, ranging from brief commentary about a particular case edit to an online debate about how to structure the course. Third, most professors have their own vision for the course materials. It may require more work to exercise it, but the online commons casebook might be one way of giving each instructor's vision more opportunity to assert itself. In fact, a result of a commons casebook project might well be more casebooks with strong theoretical bents, not fewer.

\section{Copyright Difficulties}

An online commons casebook would encounter two types of copyright difficulties: (I) users may attempt to convert the commons materials into copyrighted material, and (2) users may wish to post materials to the database that are protected by copyright. The first difficulty poses a real

75. Benkler, Coase's Penguin, supra note 2, at 393.

76. Randy E. Barnett, Contracts: Cases and Doctrine (3d ed., New York, 2003). For praise of Barnett's approach, see Kellye Y. Testy, Intention in Tension, 20 Seattle U. L. Rev. 319 (r997) (book review). 
problem to commons projects such as open-source software. If open-source software had no copyright protections whatsoever, another user could take what had already been created, make a small change to it, and then copyright the new instantiation. Thus, whole avenues of exploration could be foreclosed, and the project would likely die out. The more valuable the project, the greater the temptation to commit this sort of defection. Thus, open-source software projects often rely on a special licensing agreement which seeks to prevent this capture. The most well-known example is the GNU GPL discussed earlier, which requires derivative works to be offered to third parties without cost.

This type of capture would likely not be a problem for an online casebook. Another professor would have difficulty compiling a text from database sources and then copyrighting it and publishing it. Unless there was a lot of value added by that professor, no one would use it. The online casebook would prove a better alternative. Moreover, the managers for the commons casebook could implement an open-source license for submissions to the casebook. The license could require that submissions to the database be freely usable as long as there was no charge for such use. The Creative Commons is one place that offers a variety of licenses that can be tailored to fit particular copyright concerns. ${ }^{77}$

The second problem, however, is much more substantial. Undoubtedly an online casebook would be greatly enhanced if it could use certain types of copyrightable material. Government materials are not copyright protected and can be freely used, to an extent that may be surprising. Most secondary materials, however, such as model codes, restatement, and law review articles will have private copyright protection. Commons users will therefore need to secure permission, limit their use of such materials to fair use, or develop their own materials. These options are discussed more specifically below.

The primary source material for casebooks is cases. Early casebooks were nothing but cases..$^{8}$ Government materials such as cases, statutes, and regulations have no copyright protections against use in an online casebook.79 In fact, users of a commons casebook could use edited cases or statutes taken from Westlaw or Lexis without copyright concerns, as long as they were

77. See Lessig, Free Culture, supra note 43, at 282-86 (discussing Creative Commons licenses). It might also be noted that any professor who took original commentary from the commons, used it in a separately published work, and then attempted to enforce copyright protections against the commons would be such a pariah that social norms alone are likely to prevent such behavior.

78. See, e.g., Langdell, A Selection of Cases, supra note 5 .

79. Veeck v. S. Bldg. Code Cong. Int'l, Inc., 293 F.3d 79I, 796 (5th Cir. 2002) (noting a "continuous understanding that 'the law,' whether articulated in judicial opinions or legislative acts or ordinances, is in the public domain and thus not amenable to copyright"); West Pub. Co. v. Mead Data Central, Inc., 799 F.2d I219, I223 n.2 (8th Cir. I986) (citing Wheaton v. Peters, 33 U.S. 59I, 668 (I834) ("[N] o reporter...can have any copyright in the written opinions delivered by this court.”)); Building Officials \& Code Adm. v. Code Technology Inc., 628 F.2d 730, 734-35 (ist Cir. 1980) (discussing administrative regulations adopted wholesale from a private model code). 
shorn of headnotes, internal references, and pagination that the publisher supplied. Courts have permitted the use of the actual electronic data taken from a computer file inputted by another as long as only the "law" itself is used. ${ }^{80}$ Since most casebook editors carefully excise the publisher-added material anyway, copyright should prove no obstacle.

However, there may be a contractual barrier to the use of edited versions of Westlaw and Lexis/Nexis data files. In contracts with law schools concerning the use of their online databases, Westlaw and Lexis/Nexis have allegedly prohibited any use of their electronic data, even governmental material. ${ }^{8 \mathrm{I}}$ The database providers thus could claim breach of contract if professors posted edited versions of cases, statutes, or regulations taken from the database. I am unclear if, and how, this contractual provision would be policed. If it could be and would be, however, professors would need to edit versions of the cases taken from non-contractually-protected sources.

There are several possibilities for getting around this contractual obstacle. Many states now have their own judicial opinion and statutory databases which may have government materials which could be edited. Organizations like the Legal Information Institute are also compiling their own collections of codes, opinions, and other legal sources. ${ }^{82}$ Professors themselves could enter particular cases into electronic form or could have their administrative assistants do it. Or perhaps there is still a chance for law schools to rework this contractual provision. In any event, the database providers clearly do not have copyright protections over the material itself. So although there may be logistical hurdles to using this material, there is no question that it can be used.

Other casebook materials, however, do have copyright protections. Model codes and restatements are not the law and thus can utilize copyright protections. Model codes are not protected if they have become the law-as long as they are reprinted as the law. For example, the Uniform Commercial Code (UCC) is protected by a copyright held jointly by the American Law Institute (ALI) and the National Conference of Commissioners on Uniform State Laws. ${ }^{8}$ Even though sections of the Code have been adopted by forty-nine states, it may violate copyright law to reprint the adopted sections in their

8o. In Veeck, the operator of a non-commercial informational website had cut and pasted the text of local building codes from a version of the codes (as model codes) he purchased on a disk. Veeck, 293 F.3d at 793 . The court held that such use did not violate the copyright of the organization that had put the codes on the disk. Id. at 8 oo.

8I. These contracts are generally proprietary and confidential, but several sources have indicated that such clauses exist.

82. See Legal Information Institute, Cornell University, available at <http://www.law.cornell. edu> (last visited May I5, 2007).

83. ALI Request for Reprint Permission Form, available at <http://www.ali.org/index. cfm?fuseaction=contact.reprintpermissionform > (last visited May. I5, 2007). 
model code form. ${ }^{8}$ However, reprinting UCC sections as the law of the state of New York, for example, would be permissible. A commons casebook would thus need to use the UCC in its adopted form. Perhaps the casebook managers might ultimately choose to have versions from each state, so that casebook authors could tailor their casebooks to their own jurisdiction. ${ }^{8_{5}}$

Commons casebook users might still want to use sections of model codes that had not been adopted, or the model code commentary, or restatement provisions. Users could reprint these materials if they had appeared in a judicial opinion, as long as they were cited as such. But these restrictions would cramp the ability of a commons casebook to offer the full panoply of potential materials. Users would therefore need to secure permission to use such works or find an exception to the copyright protections such as the fair use doctrine. Permission may or may not be easy to obtain. Since a commons casebook would only be looking to excerpt sections, would not compete against actual compilations of the codes or restatements, and would be a not-for-profit enterprise, organizations holding such copyrights may be amenable to granting permission. Some organizations may already have permission policies in place that would permit use without the need for notice. ${ }^{86}$ Organizations initially hesitant to grant permission may change their mind if commons casebooks grow popular and choose to ignore the organization's materials. However, some organizations may have joint publishing or copyright agreements with legal publishers, who may be more reluctant to allow permission. ${ }^{87}$

Use of model codes or restatements in an online commons casebook might also constitute fair use of such materials. The fair use exception, unfortunately, requires a complicated, fact-based analysis of both the copyrighted source and the potential use of such material. The fair use provision allows for reproduction for "teaching (including multiple copies for classroom use)." ${ }^{88}$ However, only fair use for such purposes is allowed, and the statute discusses four non-exclusive factors in determining fair use:

84. Veeck, 293 F.3d at 800 n.I4 ("Our decision might well be the opposite, if [the user] had copied the model codes as model codes....").

85. See Neustadter, Rethinking Electronic Casebooks, supra note ig (discussing how electronic casebooks could have outline forms for each state).

86. See, e.g., Policy of the Permanent Editorial Board (PEB) for the Uniform Commercial Code Governing Permission to Reproduce or Quote from the Statutory Text and Official Comments of the Uniform Commercial Code (Code) and from the PEB Commentaries to the Code, available at <http://www.ali.org/index.cfm?fuseaction=contact.peb> (last visited May I5, 2007) (allowing unlimited use of draft codes and commentaries as well as use for "[r]easonable, limited, and selective quotation in scholarly, analytical, and critical discussions, e.g., in law reviews and texts").

87. For example, American Law Institute Publishers is a joint venture between ALI and the West Group.

88. $\quad$ I7 U.S.C. $\$ 107$ (2000). 
(I) the purpose and character of the use..., (2) the nature of copyrighted work, (3) the amount and substantiality of the portion used in relation to the work as a whole, and (4) the effect of the use on the potential market for or the value of the copyrighted work. ${ }^{89}$

Looking to these factors, use of the material in the commons casebook might very well be a fair use. The statute itself specifies that in looking at the purpose of the use, one factor is "whether such use is of a commercial nature or is for nonprofit educational purposes." 90 An open-source casebook would obviously be for nonprofit educational purposes. Regarding substantiality, commons casebook users would post only excerpts of the code or restatement provisions, thus limiting the extent of reproduction..$^{{ }^{1}}$ In terms of market effects, use of such materials in the commons casebook could increase the potential market for compilations of the codes or restatements, as the casebook would encourage students to use such materials in the future. $9^{2}$

Others, however, have been much less sanguine about using such copyrighted materials in course packets, classroom handouts, and the like. A r994 AALS report suggested that professors should obtain permission whenever using copyrighted materials in their courses. 93 The only exception is use that falls within the "safe harbor" for education fair use developed by a consortium of educators, publishers, and authors. ${ }^{94}$ This safe harbor, set forth in the 1976 educational guidelines commissioned by Congress ${ }^{95}$ is unlikely to protect commons casebook users, as it requires that " $[\mathrm{t}]$ he inspiration and decision to use such work and the moment of its use for maximum teaching effectiveness are so close in time that it would be unreasonable to expect a timely reply to a request for permission." ${ }^{6} 6$ The Report acknowledges that fair use protection undoubtedly extends beyond this safe harbor. 97 How far is uncertain. Courts have ruled

89. Id.

9o. Id. $§ \mathrm{IO}_{7}(\mathrm{I})$.

91. However, the amount and substantiality of the use might be significant if, over the breadth of the site, substantially all of the code or restatement is posted.

92. Again, however, if users have posted substantially all of the code or restatement to the site, the concern about market effects would be increased.

93. AALS Special Committee on Copyright, Photocopying of Copyrighted Materials in Law Teaching 8 (Spring 1994) (hereinafter AALS Report) (on file with author).

94. Id. at 8-9 and $\mathrm{I} 3-\mathrm{I} 5$ (Appendix. B).

95. Agreement on Guidelines for Classroom Copying in Not-for-Profit Educational Institutions with Respect to Books and Periodicals, H.R. Rep. No. 94-I476, at 68-70 (1976) (hereinafter Classroom Guidelines).

96. AALS Report, supra note 93, at I4.

97. Id. at 8. See also Kenneth D. Crews, The Law of Fair Use and the Illusion of Fair-Use Guidelines, 62 Ohio St. L.J. 599, 605 (200I) (arguing that "guidelines that purport to interpret fair use in fact bear little credible relationship to the law, and that the guidelines of the past are a weak foundation for developing new interpretations for the future"). 
that the photocopying of extensive excerpts of copyrighted materials for use in course materials is not a fair use of such materials..$^{98}$ However, the defendants in such actions were commercial copy centers that were making a profit on the copies. ${ }^{99}$ Moreover, the course materials were primarily large excerpts of academic works. ${ }^{\text {10o }}$ In such cases there are justifiable fears that the market for these works would be significantly infringed. ${ }^{\text {Ior }}$ The reproduction of short excerpts from protected works in the context of a not-for-profit textbook would seem to be distinguishable.

In sum, there are a variety of moves professors could make to get model codes and restatements into the commons casebook database. There is the possibility, however, that at the end of the day, copyright law and the lack of permission would require the exclusion of some model code and restatement materials.

The same concerns would apply to law review articles or books. Again, it might be easier to obtain permission than one might initially expect. Authors would generally be happy to give consent, given the additional audience for their work. Law reviews or legal publishers should also be willing to consent, since only excerpts would be used, users would not be making a profit from the use, and the additional exposure to their review or the publication would be beneficial. The movement within the academy for free access to law review articles is likely to reinforce the social norms in favor of permission-or may even change copyright practices. ${ }^{102}$ Eventually, law review authors may insist that law reviews or publishers allow free access to articles or books for use in projects like commons casebooks. ${ }^{103}$ Again, there may also be a fair use

98. Princeton Univ. Press v. Michigan Document Servs., Inc., 99 F.3d I38r, I39r (6th Cir. 1996); Basic Books Inc. v. Kinko's Graphic Corp., $75^{8}$ F Supp. 1522, I526 (S.D.N.Y. 199I).

99. Princeton Univ. Press, 99 F. 3 d at 1386 ("What the publishers are challenging is the duplication of copyrighted materials for sale by a for-profit corporation that has decided to maximize its profits-and give itself a competitive edge over other copyshops-by declining to pay the royalties requested by the holders of the copyrights."); Basic Books, $75^{8}$ F. Supp. at I53.

Ioo. Princeton Univ. Press, 99 F.3 3 at $\mathrm{I}_{3} 88^{-}-85$ (discussing the six excerpts ranging between $\mathrm{I} 7$ and 95 pages; the length of the average excerpt was 60 pages); Basic Books, 758 F. Supp. at ${ }_{5} 526$ (discussing 12 excerpts between I4 and IIO pages).

IOI. As the court noted in Princeton University Press:

The writings of most academic authors, it seems fair to say, lack the general appeal of works by a Walter Lippmann, for example. (Lippmann is the only nonacademic author whose writings are involved in this case.) One suspects that the profitability of at least some of the other books at issue here is marginal. If publishers cannot look forward to receiving permission fees, why should they continue publishing marginally profitable books at all? And how will artistic creativity be stimulated if the diminution of economic incentives for publishers to publish academic works means that fewer academic works will be published?

Princeton Univ. Press, 99 F.3 d at I39I.

I02. See Dan Hunter, Walled Gardens, 62 Wash \& Lee L. Rev. 607 (2005).

I03. See lessig blog, never again, available at <http://www.lessig.org/blog/archives/oo2780. shtml> (last visited July IO, 2007)("I will not agree to publish in any academic journal 
exception available, with many of the same arguments discussed in the context of restatements and model codes in play here. But it is also possible that managers will determine that some material could not be legally uploaded to the casebook database. ${ }^{104}$

Finally, there is a wealth of commentary, case notes, and problems currently written for use in copyrighted casebooks. This material could not be used without permission, and the commons casebook participants would in all likelihood have to create these materials on their own. These kinds of materials, however, would be possible to generate piece by piece, and there may already be a wealth of such materials out there for individual professors to donate. Again, it is even possible that current authors will donate their work to the commons if they see the commons as the best way of proceeding.

Thus, copyright is not likely to pose a barrier in the development of cases, statutes, or original casebook material, but it could be a problem for secondary materials like restatements, law review articles, and books. Admittedly, an online casebook would be easier to create under the aegis of Westlaw or Lexis. Users would have access to electronic versions of cases, statutes, regulations, law review articles, and even media sources. There would be no need to seek out independent copyright waivers. But we, as professors, would then be locked into using these sources and systems. They may continue to allow us free access, but they will, in all likelihood, eventually charge students. We would be doing all the work (writing the articles, editing the cases, and compiling the materials), and we would not be able to ensure continued access to it. Who knows how a publishing house might want to structure an online casebook system to maximize its profits? It seems better to make a fresh, independent start now, before we have integrated and adapted new technologies into our everyday classroom existence..$^{105}$

\section{Conclusion}

The future of legal education promises a wealth of opportunities to interact with new technologies. It is difficult to determine where it will eventually take us; the casebook itself might become extinct, or might assume a smaller role as part of a multimedia presentation on the subject at hand. ${ }^{106}$ But as we sit on the cusp of a new age, we have the opportunity to create course materials in a

that does not permit me the freedoms of at least a Creative Commons Attribution-Noncommercial license.") (last visited May ı, 2007).

I04. Other periodical publications, such as newspaper or magazine articles, would fall into the same set of possibilities, albeit with less chance of blanket permission.

I05. See Benkler, Freedom in the Commons, supra note 48, at 1276 (discussing how the legal frameworks for the use of new technologies are often established quickly after their introduction).

ro6. See Pamela Babcock, Thinking Differently, Technology Goes to School, Duke Mag., May-June 2002, available at <http://dukemagazine.duke.edu/dukemag/issues/o50602/ thinking2.html> (last visited July ı, 2007) (discussing "The Contracts Experience," a DVDROM containing written materials along with eight hours of video presentations). 
way heretofore impossible. The online commons casebook offers the flexibility of an individualized approach with the communal wisdom of hundreds of potential users. We may need a number of small-scale Linus Torvalds to begin these projects, establish their architecture, and infuse them with the energy and interest to make them a success. But the opportunity is out there, and it can start right now. 